\title{
Történelmi épületek rekonstrukciós munkálatainak támogatása pontfelhôk segítségével
}

\author{
Lovas Tamás - Rehány Nikolett - Somogyi József Árpád
}

DOI: https://doi.org/10.30921/GK.70.2018.1.3

\section{Bevezetó}

Az esztergomi királyi vár átépítési munkálataihoz szükség volt annak részletes felmérésére, építészeti dokumentációjára, mellyel a BME Építészettörténeti és Múemléki Tanszékét bízták meg. A szükséges alapvetô adatok előállítására tanszékünket, a BME Fotogrammetria és Térinformatika Tanszékét kérték fel. A történeti épületkutatás célja, hogy az épületet, annak szerkezetét, a különböző rendelkezésre álló forrásokat, szakirodalmat (szakirodalmi, tervtári, levéltári adatok, dokumentumok, ábrázolások, tervek stb.) és összefüggéseket elemezve felfedje kialakulásának körülményeit, az idôközben bekövetkezett átépítéseket és változásokat. A „Bauforschung”, azaz épületkutatás módszerének alkalmazásával az építészek az építmény lehetô legkisebb mértékú roncsolása mellett tudják a vizsgálatokat elvégezni (Grossmann 1993, Krähling et al. 2006, Krähling 2017, Schuller, 2002). A módszer elsôdleges eszköze az alakhú felmérés, amelynek lényege, hogy a helyszíni felmérést végzôk által definiált, tetszôleges koordináta-rendszerben részletesen és pontosan rögzíti az egyes elemek formáját (kôelemek, téglák sarokpontjait), helyét, méreteit, így mentes bárminemú feltételezéstôl és szabályosságkereséstôl. Mivel a rajz a helyszínen készül, nem csak a szemmel látható, de a tapintható sajátosságok is észlelhetôk, így sokkal inkább értelmezve rajzolásról beszélünk, mint hagyományos rajzkészítésrôl. Rajzolás közben olyan információkat is rögzítenek grafikus vagy szöveges formában, mint a repedések, mállások, kőfaragójelek, javítások, különbözó anyagtípusok, vonóvasak nyomai, ékek, pótlások. A rajzot olyan minôségben és részletességgel készítik el a szakemberek, hogy az a késóbbi kutatások számára is forrásértékú lehet. Az elkészült rajzokat digitalizálják, összeillesztik, majd vektoros állományt készítenek belőle, azaz minden egyes követ átrajzolnak CAD-környezet (többnyire AutoCAD vagy ArchiCAD) segítségével (Hajnóczi 1956, Halmos-Marótzy 2010, Krähling 2017).

A hagyományos felmérés során, pontosan kitǔzött, a falra kifeszített vízszintes és függóleges zsinórokkal dolgoznak az építészek. Egyikük beméri a kitúntetett pontokat a referenciavonalakhoz viszonyítva, a másik szakember eközben a meghatározott méretek alapján, a helyszínen elkészíti a rajzot (Halmos-Marótzy 2012, Halmos et al. 2013, Krähling et al. 2006). Más módszerekkel kevesebb idôt szükséges a helyszínen tölteni; a falat alkotó kövekról csak vázlatos rajzok és fényképek készülnek, a jellemzố pontokat pedig mérőállomással mérik meg. A rajz pontosítása irodai körülmények között zajlik, azonban a kiegészítő információk (pl. sérülések, jelek a köveken) miatt szükség van további helyszíni szemlére. Kissé eltérố technikát alkalmazva pedig az építészek egy előzetes pl. mérôállomással végzett mérés adataiból készített, egyszerúsített, de pontos vektoros rajzot visznek ki ismét a helyszínre, amire helyben felviszik a pontos geometriát és az egyéb fontos információkat (Halmos-Marótzy 2010,, 2012, Halmos et al., 2013). Fotótahimetriát is használnak általános építészeti felmérések támogatására (Scherer 2005). Olyan fejlesztéssel is lehet találkozni, ami segíti az épület alkotóelemeinek 3D-s modellezését, és lehetôvé teszi a virtuális megjelenítést, valamint egy kapcsolódó adatbázisban tárolja a lényeges adatokat (Drap et al. 2009).

Fontosnak tartjuk megjegyezni, hogy a manapság egyre szélesebb körben alkalmazott lézerszkennelés önmagában nem tudja kiváltani az értelmezve rajzolás helyszíni felmérési munkarészeit, de jól kiegészíti, segíti, például az összetett, szabálytalan alakú helyiségek, valamint nehezen megközelíthetô, magas részek felmérésével. A fotogrammetria sem alkalmas önmagában a részletes építészeti felmérés egészének helyettesítésére (a képeken nehéz megkülönböztetni az egyes anyagokat, a falon lévố szennyeződések, esetleges árnyékok megtévesztôk lehetnek, kitakarások jelentkezhetnek, például növényzet és állványozás révén), de jó alapot szolgáltathat hozzá.

\section{Méréstervezés}

A történeti épületkutatás elsô lépése a meglévô állapot lehetô legpontosabb és legteljesebb dokumentálása, melynek elôkészítô munkálatát, azaz a valós geometria felmérését tanszékünk hajtotta végre. Az átépítéshez szükséges alapvetô építészeti termékeken (alaprajzok, metszetek) kívül a vár teljes felmérendố területén, minden egyes helyiség összes faláról ortogonális nézeteket szolgáltattunk képek formájában.

A felmérés előkészületei során általában geodéziai méróállomással végeznek méréseket, mi azonban az összetett, tagolt geometria (szúk folyosók, meredeken emelkedô lépcsôk, változatos geometriájú, esetenként szúk helyiségek, bonyolult, díszes kapuk) miatt a felméréshez a földi lézerszkenner alkalmazása mellett döntöttünk. A vár külsố oldalán a magasabb részek és a teljes tetô felmérésére UAS- (Unmanned Aerial System) fotogrammetriát választottuk adatgyújtési technológiaként (1. ábra). Az eszköz által készített képekbôl fotogrammetriai módszerrel pontfelhő állítható elő. Ahhoz, hogy a különbözô forrásból származó pontfelhôk közös, geodéziai koordináta-rendszerbe történô illesztésére sor kerülhessen, GNSS-méréseket is végeztünk a másik két méréssel egy időben, melyre azért is szükség volt, hogy a felmérés eredménye összehasonlíthatóvá váljon a korábbi felmérésekkel (Rabb 2004).

Az ortogonális nézetekhez hagyományosan jó minôségú, nagy felbontású DSLR-kamerával szokás elkészíteni a képeket a fal síkjára közel merólegesen, 

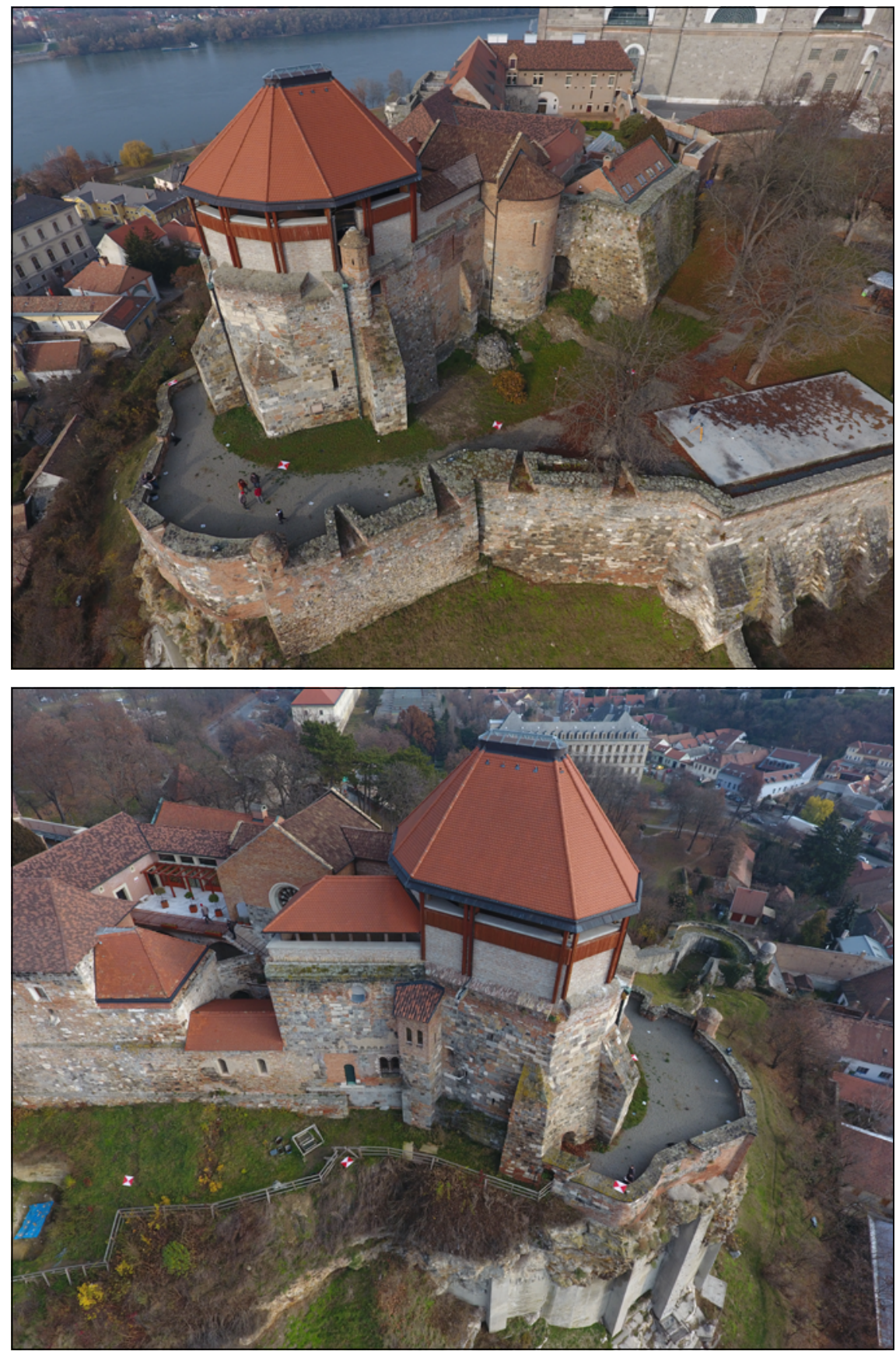

1. ábra. UAS-sel készített fényképek a várról.

Ezekbốl vezettük le azt a pontfelhôt, amely kiegészítette a földi lézerszkenneres felmérést.

azonban a sötét helyiségek és a csak nehézkesen megoldható megvilágítás (elektromos hálózat hiánya, nagyon tagolt - ezáltal árnyékos - falfelületek) miatt erre nem volt lehetôség. Földi lézerszkennelésre a többi feladatrész előállításához mindenképp szükség volt, így a pontfelhố rendelkezésünkre állt, így kézenfekvô volt annak használata az ortogonális nézetek levezetéséhez is. A vár belsejében, a sötét helyiségekben fényhiány miatt értelmetlen lett volna fényképeket készíteni a lézerszkennerrel, ezért nem állítottunk elô által nem látható felületekrôl DJI Phantom 4 típusú quadrokopterrôl, FC 330-as akciókamerával készítettünk felvételeket. RTK GNSS-technológiával a drónos és lézerszkenneres felmérés által használt, kihelyezett illesztôpontok koordinátáit határoztuk meg a másik két méréssel összehangolva, egy idôben. A lézerszkenneres álláspontok számát az épület összetettsége határozta meg. Mint említettük, sok kisebb helyiséget kellett felmérni (ügyelve a kitakarások elkerülésére), majd egy rendszerbe illeszteni. A szkennelési felbontást (pontközt) az ortonézetekhez szükséges geometriai felbontáshoz kellett igazítani. Az építményt a kiegészítő mérésekkel együtt összesen 147 álláspontból mértük fel, öt alkalommal. Eredményül több mint 6 milliárd pontot tartalmazó pontfelhôt kaptunk, a nyers adatok mérete összesen 31 GB lett. A használt lézerszkenner 2 mm-es távolságmérési középhibával rendelkezik, valamint maximális felbontás mellett a pontköz 10 méteres távolságban $\sim 1,5 \mathrm{~mm}$. A felmérés során a beltéri szkennelésekkor negyedes felbontást ( $\sim 6 \mathrm{~mm}$-es pontköz 10 méteren) használtunk, míg a külsô részeken, ahol nagyobb távolságban lévố részleteket is kellett mérni, a feles felbontást ( $\sim 3$ mm-es pontköz 10 méteren) találtuk megfelelónek. Fényképeket csak a külsô részeken készítettünk, ahol a fényviszonyok ezt lehetôvé tették, ezáltal csak a kinti részrôl lehetett valódi színes pontfelhôt elóállítani. A nagy területre kiterjedô, több sokszögvonal vezetését kívánó mérések során, az egyes álláspontokon mért pontfelhőket kapcsológömbök segítségével illesztettük össze. UAS-sel 456 db (4000 × 3000 pixel méretû) fénykép készült, amelyekbôl a szkenneltnél ritkább pontfelhôt lehetett elóállítani, ami az összeillesztett állományon is jól megfigyelhetô (6. ábra). A késôbbi mérések során pontfelhô-pontfelhô illesztési technológiát (Iterative Closest Point - ICP) alkalmazva illesztettük be a kiegészítố méréseket a már meglévô, összeillesztett állományba a megfelelô átfedés biztosítása mellett. Az álláspontonként kiexportált pontfelhôk egybevonása után, azok méretei miatt nagyon nehezen lett volna egyben 
kezelhetô, ezért 1 cm-es pontközzel újramintavételeztük az állományt. A mérések összeillesztéséhez és feldolgozásához a szkenner gyártójának saját programját, a Faro Scene-t, valamint a nyílt forráskódú CloudCompare-t használtuk. Az így előállt, lézerszkenneres és drónos méréseket egyaránt tartalmazó, redukált pontfelhô kb. 80 millió pontból állt. Az alaprajzok és építészeti

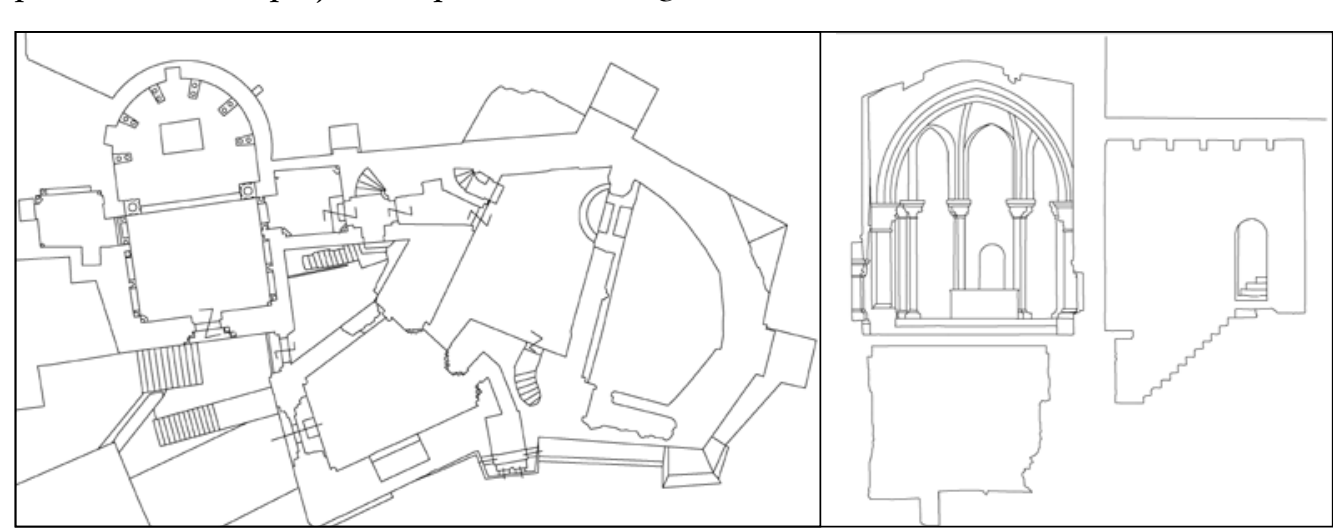

2. ábra. A kápolna szintjén felvett alaprajz (bal), valamint a kápolnát keresztezố metszet (jobb).

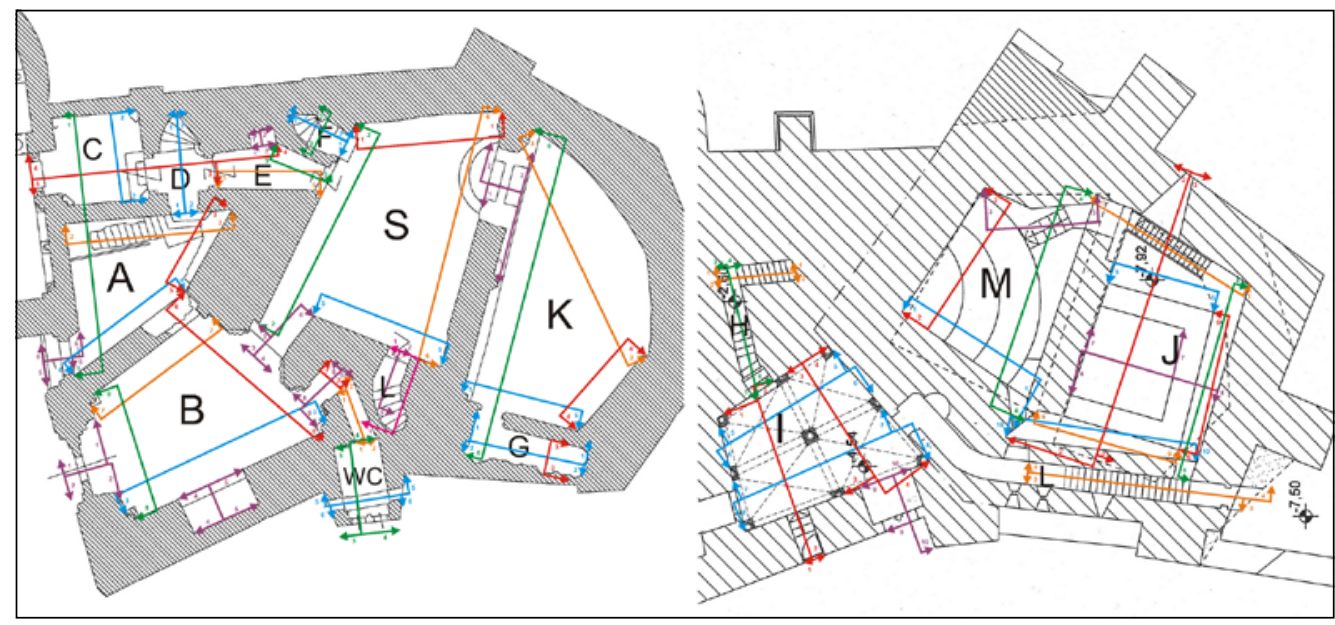

3. ábra. A földszint (bal) és az alagsori szint (jobb) alaprajza az épitészek által definiált síkok helyének jelölésével.

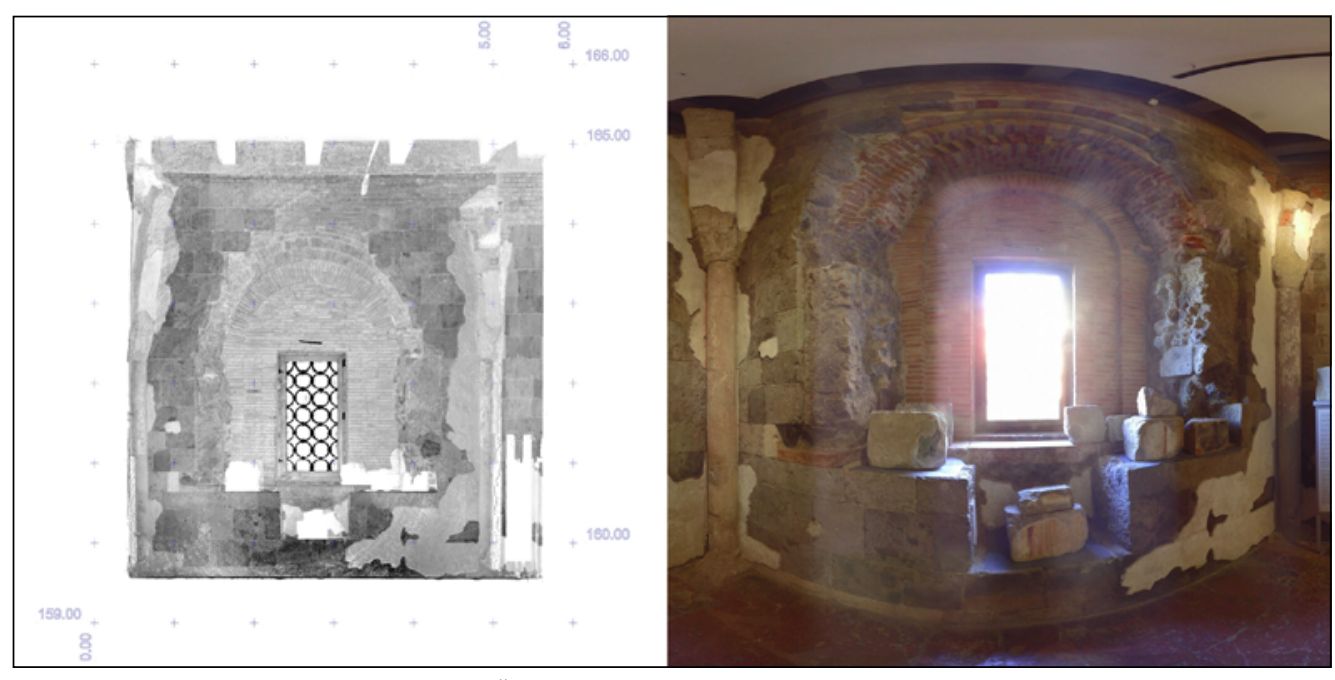

4. ábra. Ôrkereszthálóval ellátott ortonézet (bal)

és a szkenner által készített fényképrészlet (jobb) ugyanarról a falszakaszról.
Az elő́állt egységes pontfelhôn utólagosan, tetszőleges helyeken vehetôk fel a keresztmetszetek. A vár esetében 4 szintrôl készültek alaprajzok, és további 14 vízszintes, valamint 7 függőleges metszetet vettünk fel az építészeti munkálatok támogatására (2. ábra). A részletes és felületjellegú adatnyerési módszerek magas szintű modellezést tesznek lehetôvé, szemben a diszkrét pontok mérésével.

A falakról történô ortonézetek készítéséhez az eredeti pontsúrúségú pontfelhôból kivágtuk az érdeklôdési területnek megfelelố pontfelhốrészletet, majd megtisztítottuk az olyan, oda nem illő pontoktól, mint az állványok, táblák, kiállított tárgyak, emberek, paravánok. Az építészek a legtöbb esetben a falsík irányára illeszkedô, de teljesen függőleges síkokat, mint vetítôsíkokat definiáltak, esetenként ettől eltérô, másik falsíkkal párhuzamos, de függóleges síkokat határoztak meg (3. ábra). Az egyes falakhoz tartozó pontfelhôket a hozzájuk tartozó, elôre definiált síkra vetítettük, majd a pontok pixelméretének beállítása után legeneráltuk az ortogonális nézeteket JPGformátumban. Azért, hogy az építészek a nagyobb falakról készült képeket szét tudják darabolni, majd késóbb pontosan összeilleszteni, az ortonézeteket méteres osztású ôrkereszthálóval láttuk el, amelynek vízszintes tengelye a balti alapszint feletti magassághoz igazodik, a függőleges kezdőtengely pedig tetszóleges helyról, az ábrázolt falnézettől balra indul (4. ábra). Az épület felmért része több szintet is tartalmaz, így bizonyos falaknál azonos síkot kellett alkalmazni az egymás feletti falakról készülô ortonézetek esetén, valamint az ôrkereszthálózatnál 
is ugyanazt a koordináta-rendszert használtuk. A J-vel jelölt teremben (3. ábra) egy kiásott falszakaszt is találtak, melynek alapos dokumentálásához egy felülnézeti ortonézetre is szükség volt, ami a szomszédos (M jelú) helyiséget is tartalmazta. Itt vízszintes síkot vettünk fel, és arra merőlegesen, tehát felülrôl készítettük el az ortonézetet, a hozzá tartozó rácshálót pedig az EOV-rendszerhez igazítottuk. Egy másik alagsori helyiségben, az I-vel jelölt Szent István teremben boltozatok alkotják a mennyezetet, amit az építészek szintén dokumentálni kívántak, így errôl is szükséges volt egy ortonézetet készíteni. Ebben az esetben is vízszintes síkot alkalmaztunk, és alulról felfele nézve forgattuk be a pontfelhôt. Összességében a vár körül 20, a belsejében $100 \mathrm{db}$ falról, falszakaszról, valamint egy felülnézeti és egy alulnézeti ortogonális képet készítettünk.

Az átadott ortonézeteket az építészek képszerkesztô programmal halványították, megváltoztatták a színek tónusát, illetve számukra megfelelố módon feldarabolták, majd 1:50 méretarányban kinyomtatták. A helyszínen, a kinyomtatott ortonézetekre rajzolták az egyes kontúrok valódi helyét, valamint az egyéb kiegészítô információkat. Az elkészült rajzokat ezután beszkennelték és összeillesztették. A nyomtatás elôtti módosításoknak (pl. kontrasztállítás) köszönhetôen a szkennelés után nem látható a halványított pontfelhô, de az emberi szem számára a lapon kinyomtatva még érzékelhető, így segíteni tudta a rajzolást. Ennek a felmérésnek a szkennelt rajz volt a végeredménye, nem vektorizálták óket. Az 5. ábrán látható az ortonézet és az alakhú felmérés eredménye azonos falszakaszra vonatkozóan.

Az elôre definiált feladatokon túl előállítottuk a terület „utcaképnézetét”, amelynek segítségével virtuálisan lehet lépkedni az egyes szkennelési álláspontok között, és körbetekinteni az egyes helyeken (a Google StreetView-hoz hasonlóan), így panorámaképeken keresztül láthatjuk azt, amit a szkenner látott. Ennek elkészítéséhez rendelkezésünkre álltak az egyes álláspontokon a szkenner helyének és helyzetének információi, valamit az intenzitás szerint színezett pontfelhôkbôl generált (színes pontfelhố esetén pedig a fényképekből készített) panorámafényképek. Ennek használata megkönnyítette a feldolgozást, pontfelhôkezelô szoftver nélkül, gyorsan meg lehetett nézni, hogy az egyes álláspontokról pontosan mi látszódott a mérés során, valamint, melyek a szomszédos álláspontok, és egy-egy helyiséghez mely álláspontok tartoztak. Nem utolsó sorban pedig az építészek munkáját is segítheti, ha az irodában ülve felmerül egy-egy kérdéses rész az épületen, csak el kell „sétálni” addig a helyiségig és ránagyítani az érintett falszakaszra.

\section{Felmerült problémák}

A külsố ortonézetek elkészítése során láthatóvá vált, hogy a két különbözô forrásból származó pontfelhố nem egyforma pontsúrúségú. Az UAS-es pontfelhố ugyan kiegészíti a lézerszkennerrel készült pontfelhố hiányosságait, azonban a feladathoz nem kellóen részletes, nem különülnek el rajta az egyes kövek, téglák, ahogy az a 6. ábrán is megfigyelhetô. Az egyesített pontfelhô átlagos pontsû́rúségét az 1. táblázat szemlélteti.

\begin{tabular}{|l|l|r|}
\hline & & Pont $/ \mathrm{m}^{2}$ \\
\hline \multirow{3}{*}{ Belsố } & Minimum & 154414 \\
\cline { 2 - 3 } & Átlagos & 2662554 \\
\cline { 2 - 3 } & Maximum & 10622378 \\
\hline \multirow{3}{*}{ Külsố } & Minimum & 6891 \\
\cline { 2 - 3 } & Átlagos & 114343 \\
\cline { 2 - 3 } & Maximum & 2002183 \\
\hline
\end{tabular}

1. táblázat. Egyesített pontfelhố jellemzó pontsürüségi értékei

Ahogy említettük, a külsô terület felmérésekor fotókat is készített a szkenner, így rendelkezésünkre állt a színes pontfelhô is az intenzitás szerint színezett mellett. Az UAS-pontfelhô valódi színes volt, így a lézerszkennelt külsố pontfelhôknél is a színeseket használtuk fel az egyesített pontfelhô elkészítéséhez. A két különböző fényképezôgéppel készült képek színei sem teljesen egyeztek meg, valamint a mérés során a különböző álláspontokból a szkenner

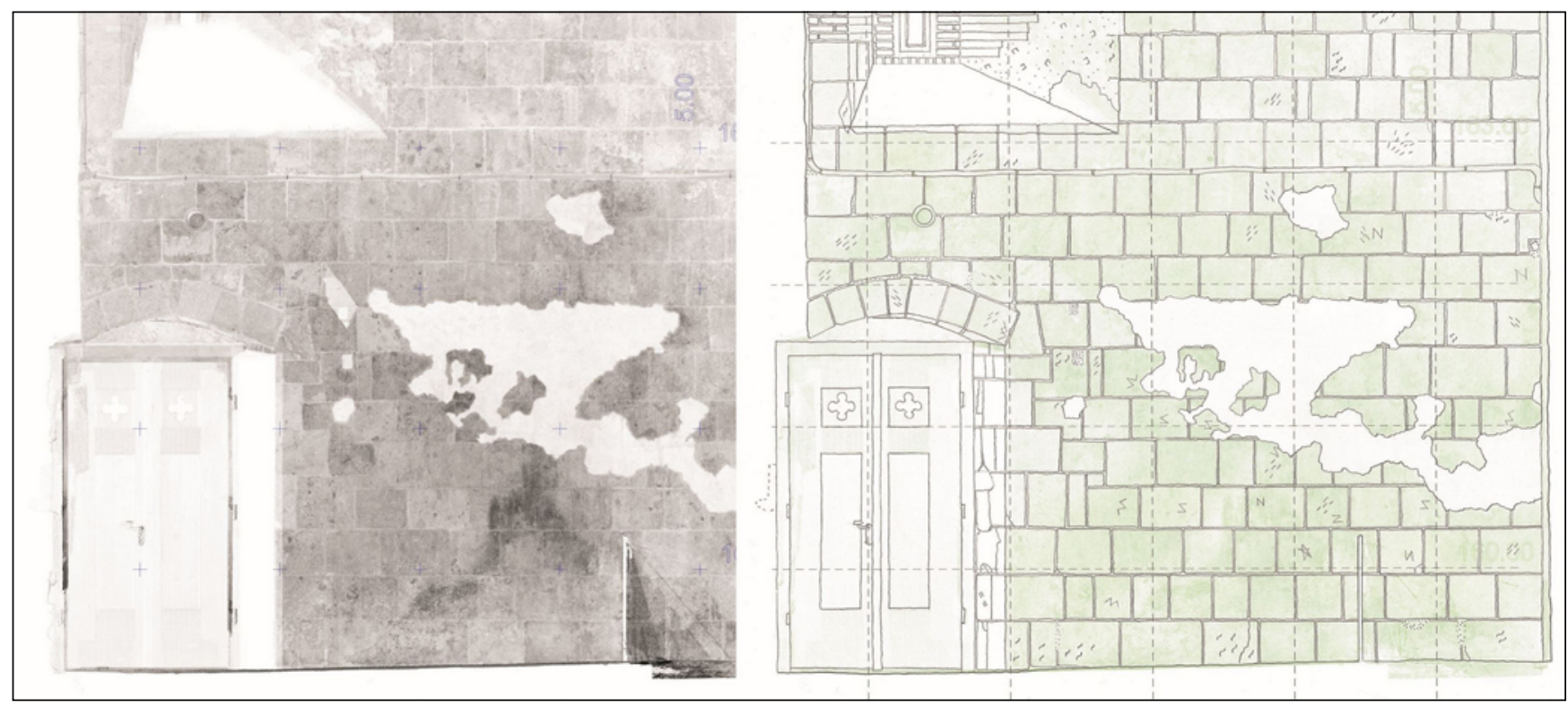

5. ábra. Egy falszakasz ortonézete (bal) és az épitészek által ez alapján készített helyszini felmérés eredménye (jobb). 


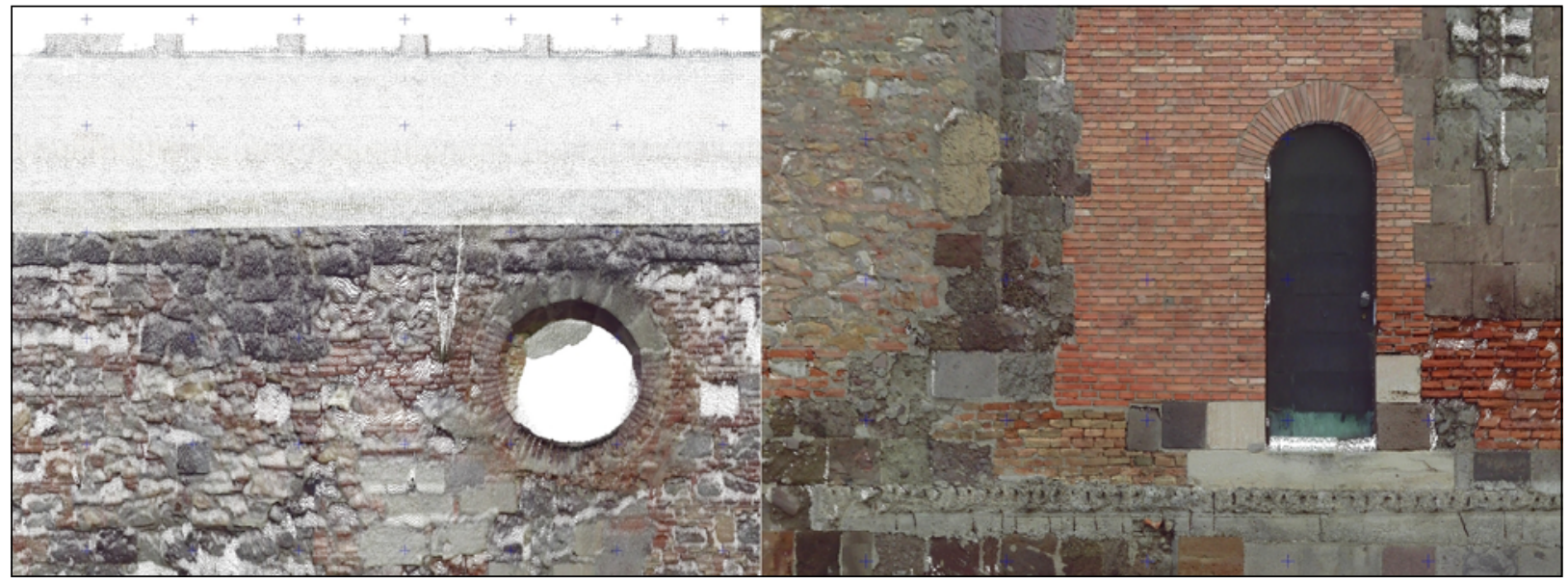

6. ábra. Lézeszkennerrel és drónnal készített, egyesített, újramintavételezés nélküli pontfelhốbốl levezetett ortonézet részlete a vár egy külsô, tetốközeli szakaszáról (bal), valamint egy alsóbb szakaszáról (jobb).

által fotózott falak kissé eltérố színben látszanak a nap járásának, a felhôzet változásának és az árnyékok vonulásának következtében. Több helyen gondot okozott az erôs napsütés miatt beégett fénykép.

Fontos megjegyezni, hogy az intenzitás szerint színezett, szürkeárnyalatos pontfelhố nem egyenértékú azzal, mintha a színes pontfelhốt alakítanánk át szürkeárnyalatosra. Az intenzitásértékek ennél jóval több információt hordoznak a felület anyagáról (Berényi et al. 2010), ami egy ilyen esetben, mikor hasonló színú, de mégis eltérố felületkiképzésû́ elemeket kell lehatárolni, hasznosnak bizonyul. A 7.ábrán jól megfigyelhetô az eltérés.

A beltéri mérések során is készítettünk próbaképpen valódi színes pontfelhôket, azonban azok a legjobban bevilágított helyiségben sem bizonyultak használhatónak. A váron belül ezért csak intenzitásalapú pontfelhôket használtunk, aminek szintén megvannak a maga korlátai. Ha a szkenner gyártója által megadott távolságnál közelebb létesítettünk álláspontot a falhoz (ami a szúk lépcsőknél elkerülhetetlen volt), akkor a pontfelhố koncentrikus, beégésszerú színezetú lett az egyébként teljesen sima, egységes falszakaszon (8. ábra), aminek következtében vesztett az építészek számára lényeges információtartalmából.

\section{Összefogalás}

Adatgyújtési és -feldolgozási munkafolyamatot fejlesztettünk a történeti épületkutatás támogatására olyan

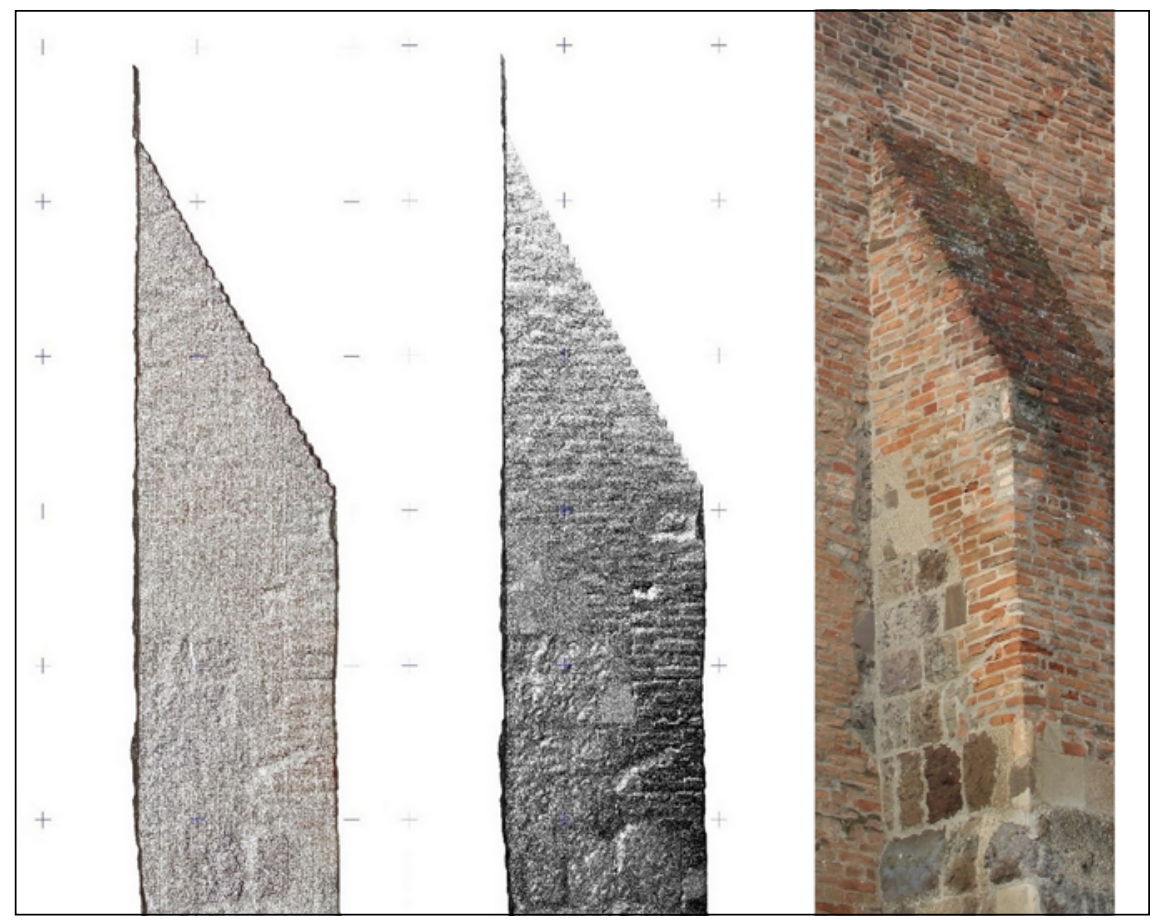

7. ábra. Valódi szines (bal) és intenzitás szerint szinezett (középsô) pontfelhô, valamint a helyszinen készült dokumentációs fénykép (jobb).

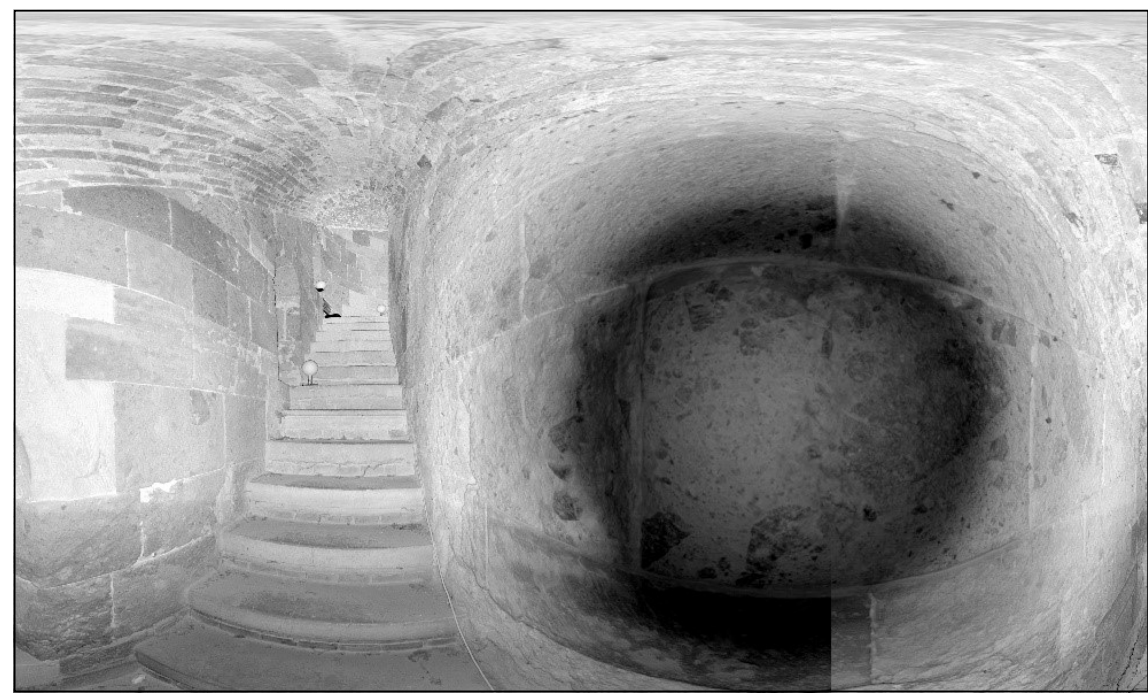

8. ábra. Beégett falszakasz a szük lépcsôsor egyik álláspontjáról készült pontfelhő panorámaképén. 
körülmények közt történô alkalmazásra, ahol a hagyományos, optikai szenzorokkal nem lehetséges a szükséges termékek elóállítása. A lézerszkennelt pontfelhőből levezetett intenzitásalapú ortonézetek sötét helyiségekben, tagolt falfelületek esetén is hatékonyan támogatják a helyszíni építészeti munkát. A teljes látható felület felmérésének következtében tetszôleges vetítô síkok vehetôk fel, így pl. mennyezetrôl és padlóról is előállíthatók nézetek. A felmerülő problémák kezelésére a helyszíni felmérés adaptív paraméterezésével, tehát a szükséges helyeken az álláspontok sû́rítésével és a környezetnek megfelelő felbontás kiválasztásával, a különböző forrásból nyert pontfelhôk egyesítésével sikerült megoldásokat találtunk.

\section{Kitekintés}

A pontfelhőalapú ortonézetekkel felgyorsítható és megkönnyíthető az építészek munkája, azonban még mindig lehetne javítani a hatékonyságon. Terveink között szerepel egy olyan munkafolyamat kidolgozása, amely lehetôvé teszi, hogy az építészek ki tudják vinni a helyszínre - digitális formában - a pontfelhốrôl készült ortonézetet, és azt alapként használva közvetlenül vektoros felülrajzolást végezzenek, ezáltal kiváltható a kép kinyomtatása, a ceruzás rajzolás, majd a digitalizálás. A célunk olyan GIS-szoftver bevonása, aminek segítségével a rajzi elemekhez egyből hozzárendelhetôk, rögzíthetốk a lényegi információk, jellemzók, akár szöveges, akár rajzi jelölés formájában. Az építészek kövenkénti fotódokumentációt is szoktak készíteni, amivel szintén ki lehet egészíteni a mérést. Ha például egy tableten rajzolnának, és ugyanazzal az eszközzel készítenék a képeket is, akkor már a felmérés közben hozzá lehetne rendelni a képeket az egyes kövekhez, akárcsak az attribútumokat. Az építészek által használt jelenlegi munkafolyamat is lehetóvé teszi a vektorizált adat és a lejegyzetelt fontos jellemzók, jelkulcsok utólagos egyesítését, a felmérési rajzhoz rendelt adatbázis létrehozását. A gyakorlat azt mutatja, hogy ez az idôigényes utómunka a legtöbbször elmarad, pedig ezáltal lehetne mások számára is könnyen értelmezhetôvé, kezelhetôvé tenni a kutatás eredményét (HalmosMarótzy 2010).

\section{Köszönetnyilvánítás}

Köszönjük a BME Építészettörténeti és Múemléki Tanszék munkatársainak a munkában való közremúködés lehetôségét. A szerzők köszönettel tartoznak Hadzijanisz Konsztantinosznak és Pipis Lászlónak a kiváló minôségú UASfelvételek elkészítéséért.

\section{Irodalomjegyzék}

Berényi A. - Lovas T. - Barsi Á. (2010) Földi lézerszkenner laboratóriumi vizsgálata. Geodézia és Kartográfia, vol. LXII (4), pp. 11-16.

Drap, P. - Seinturier, J. - Chambelland, J.-C - Gaillard, G. - Pires, H. - Vannini, G. Mucciotti, M. - Pruno, E. (2009) Going to Shawbak (Jordan) and getting the DATA back: toward a 3D GIS dedicated to medieval archaeology. 3D Virtual Reconstruction and Visualization of Complex Architectures, vol. XXXVIII-5/W1, 2009. február [3rd ISPRS International Workshop 3D-ARCH, 2009].

Grossmann, G. U. (1993) Einführung in die Historische Bauforschung. Wissenschaftliche Buchgesellschaft, Darmstadt.

Hajnóczi Gy. (1956) Mûemlékfelmérés. Az Építôipari Múszaki Egyetem Tudományos Közleményei, vol. I/6, Budapest.

Halmos B. - Marótzy K. (2010) The adaptations of the true-to-form survey method. Periodica Polytechnika Architecture, vol. XLI (1), pp. 9-17. DOI: https://doi.org/10.3311/ pp.ar.2010-1.02

Halmos B. - Marótzy K. (2012) Észrevételek a gyulafehérvári Szent Mihály-székesegyház szentélyének felmérése nyomán. A gyulafehérvári székesegyház fôszentélye, Szerk Papp Sz., Budapest, Teleki László Alapítvány, pp. $43-58$.

Halmos B. - Marótzy K. - Nagy G. D. (2013) A gyulafehérvári székesegyház déli tornya Dolgozatok az Erdélyi Múzeum Érem- és Régiségtárából, vol. XVI-XVII., Szerk.: Bajusz I. - Emődi T. - Benkô E. - Kovács A. - László A. Kolozsvár, Erdélyi Múzeum-Egyesület, pp. 217-239.

Krähling J. - Halmos B. - Fekete J. Cs. (2006) A fertődi marionettszínház új értelmezése az épületkutatás ("Bauforschung") és alakhû felmérés mint kutatási módszer alkalmazásával. Építés-Építészettudomány, vol. 34 (1-2), pp. 5-55. DOI: https://doi.org/10.1556/ EpTud.34.2006.1-2.1

Krähling J. (2017) Épületkutatás és építészettörténet - néhány újkori és 19 . századi épülettípus kutatásának módszertana és eredményei. Habilitációs tézisek, Építés-Építészettudomány, vol. 45 (3-4), pp. 341-364. DOI: https://doi. org/10.1556/096.2017.45.3-4.6

Rabb P. (2004) Fejezetek az esztergomi várhegy középkori épületeinek utóéletébôl. Építés-Építészettudomány, vol. 32 (1-2), pp. 87-135. DOI: https://doi.org/10.1556/ EpTud.32.2004.1-2.3

Scherer, M. (2005) Architectural Surveying and Visualization Using "Photo-Tacheometry".
From Pharaohs to Geoinformatics, Kairó Egyiptom, 2005. április [FIG Working Week 2005 and GSDI-8].

Schuller, M. (2002) Building Archeology Monuments and Sites, vol. VII, MünchenParis: ICOMOS

\section{Summary}

Architects ordered the complex building survey of the Royal Castle of Esztergom and generating architectural products like floor plans, cross sections and orthoviews of the walls to support reconstruction works. Due to certain specialities of the castle like extension of the walls (both vertical and horizontal), fragmented and irregular surfaces, dark rooms inside, we decided to use laser scanning technology combined with Unmanned Aerial System (UAS) photogrammetry for surveying. Latter was used outside the building and GNSS measurements ensured merging the point clouds from the different sources together. Current paper presents how the mentioned architectural products were derived from point clouds and discusses how efficiently laser scanned data and point cloud derived from UAV could be used.

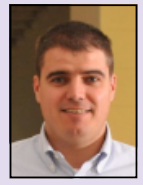

\section{Dr. Lovas \\ Tamás egyetemi docens}

BME, Fotogrammetria és Térinformatika Tanszék lovas.tamas@epito.bme.hu

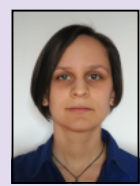

Rehány Nikolett doktorandusz

BME, Fotogrammetria és Térinformatika Tanszék rehany.nikolett@epito.bme.hu

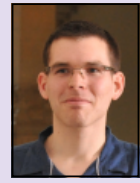

Dr. Somogyi József Árpád adjunktus

BME, Fotogrammetria és Térinformatika Tanszék somogyi.arpad@epito.bme.hu 